\section{E A Institute of \\ YK Business Administration \\ 光 \\ Karachi \\ Leadership and Ideas for Tomorrow}

\section{Business Review}

Volume 4 Issue 2 July-December 2009

$7-1-2009$

\title{
Back Matter of Volume 4 Number 2
}

Tufail A. Qureshi

Institute of Business Administration, Karachi, Pakistan

Follow this and additional works at: https://ir.iba.edu.pk/businessreview

Part of the Business Commons

c) (i)

This work is licensed under a Creative Commons Attribution 4.0 International License.

\section{Recommended Citation}

Qureshi, T. A. (2009). Back Matter of Volume 4 Number 2. Business Review, 4(2), 155-162. Retrieved from https://doi.org/10.54784/1990-6587.1339

This article is brought to you by iRepository for open access under the Creative Commons Attribution 4.0 License and is available at https://ir.iba.edu.pk/businessreview/vol4/iss2/13. For more information, please contact irepository@iba.edu.pk. 


\section{IBA \\ 米}

\section{A WORD ABOUT THE IBA}

Our logo reflects "our resolve to meet the future challenges with integrated and multidisciplinary knowledge and its creative application in a changing global environment."

\section{INTRODUCTION}

The IBA is the oldest business school outside North America. It was established in 1955 as a USAID financed project. Initially, the Wharton School of Finance, University of Pennsylvania, provided the technical support. Later, the University of Southern California got the contract to set up various facilities at the institute and several prominent American professors were assigned to IBA. A large number of Pakistani faculty members received advanced degrees from Wharton and University of California. In 1994, the Sindh Assembly elevated the Institute's status to that of a degree awarding institution.

Despite of a rapid increase in the number of business schools, the IBA has maintained its position as the premiere institution of higher learning in the field of management and business administration. The IBA sets the standards of educational and professional excellence. It seeks to advance and encourage new ideas and promote enduring values to guide the practice of management. Over the years, the IBA has built a reputation for producing graduates of unmatched professionalism and sound ethical and moral values. The IBA has an academic environment in which talented and outstanding young men and women are inspired to reach out to the farthest limits of their vision and capacities.

The IBA is proud of its 8,000 plus accomplished alumni who are engaged in highly specialized and professional undertaking all over the world. Many of them hold demanding positions of administrative responsibilities in various fields of governance in Pakistan and abroad. We proudly celebrate their association with the IBA.

\section{CORE VALUES}

We uphold:

- Merit - Truth - Integrity

- Creativity - Discipline Tolerance

- Humility 
as the creative dimensions of the "highest good" - summum bonum - of an ethically motivated academic life based on moral foundations.

\section{MISSION}

With a legacy spanning more than five decades of excellence, the IBA is geared up to achieve more milestones in the field of education, providing its commitment to the ideal of continuous improvement.

At the IBA, our mission is to provide education and training for management leadership in private and public sector in Pakistan. To reinforce this commitment, the Director IBA, Dr. Ishrat Husain, has presented a five year strategic vision for the institution. The vision is based on infrastructural expansion, faculty and technology up gradation and extending linkages to the industry, with the aim of being among the best business schools of the region.

\section{PHILOSOPHY}

Our pedagogical philosophy is rooted in the creative urge to strive continuously to improve upon all components of our system; culture, people and infrastructure; and to turn bright students with leadership potential into outstanding human beings, business professionals and leaders for tomorrow.

\section{MEETING THE CHALLENGES}

In the dynamic and ever changing business landscape, IBA is faced with numerous challenges. It, therefore, keeps on enhancing its curricula to make it relevant to the practical and corporate world. The faculty, staff, students and professionals work together to achieve learning goals. Students acquire knowledge and skills through constructive and distinctive processes that encourage them to develop understanding of business concepts and issues, to think independently and to make rational choices. They are encouraged to take responsibility for their own learning, to become active participants and leaders and to apply their knowledge in real-world context.

\section{THE GOALS AHEAD}

IBA aims to go global and keeping this in mind has entered into collaboration with renowned international academic and business partners. It is proud of its alliances with Microsoft, Oracle, SAP, CFA, IFC and Solbridge Business School. The IBA is set on a path of constant improvement, introducing changes in all critical fields of its undertaking. Its computer science program is placed in the highest rated category "W" Computer Science Program in the country. It has agreements with various government bodies to impart quality education in the field of management. In this regard the IBA 
has launched FBR Capacity Building Program which aims to upgrade the quality of human resource in the public sector.

\section{PROGRAMS OF STUDY AT THE IBA}

The IBA programs are designed to provide world-class professional training to managers and entrepreneurs for the business and industry in Pakistan. Students take part in a broad variety of activities ranging from volunteering for charity work and participating in athletic events to organizing conferences on a variety of business issues. The spirit of involvement is important because teamwork, leadership and being a responsible citizen are the foundations of the IBA experience.

Our programs have been growing steadily in keeping with the needs of the society and the competence of the Institute of Business Administration. We offer courses in the fields of:

- Doctor of Philosophy - Ph.D. (MIS/ Information and Communication Technologies (ICT)/ Computer Science \& Engineering (CSE)

- Master of Business Administration - MBA (Morning Program)

- Master of Business Administration - Management Information System MBAMIS (Morning Program)

- $\quad$ MS (Economics)

- $\quad$ MS (Finance)

- Master of Business Administration - MBA (Evening Program)

- $\quad$ EMBA for Corporate Managers

- $\quad$ EMBA for Public Sector

- $\quad$ EMBA-Business \& Finance

- $\quad$ Postgraduate Diploma in Business Administration - PGD (Evening Program)

- $\quad$ Certificate Courses (Evening Program)

- Visiting Students (Evening Program)

- Master of Business Administration - Tax Management (Morning Program)

- Bachelor of Business Administration - BBA (Morning Program)

- Bachelor of Business Administration - Management Information Systems BBA- MIS (Morning Program)

- Bachelor of Science - BS (Morning Program)

\section{CAREER OPPORTUNITIES}

In view of the increasing professionalism in management and growing competition in Pakistan, job opportunities for qualified and trained business administration graduate will continue to grow. Multinational firms and professionally managed Pakistani companies hire IBA graduates with confidence because of the high level of professionalism 
instilled in them during their course of study. The interaction of researchers, business and industry is necessary for the development and implementation of the new and relevant ideas. The Research Wing undertakes projects and assignments specific to a particular industry or an organization covering diverse fields of management, finance and marketing.

\section{CENTER FOR EXECUTIVE EDUCATION}

The strategic location of IBA in Karachi, the business and financial capital of Pakistan, the long standing reputation of IBA, with its brand name and a vast network of alumni spread over the corporate sector, are the assets utilized by the CEE. The center offers two Executive MBA programs - one for the public sector managers and another for middle level corporate managers. Soon it will also be offering short term (of 3 months duration) training courses in the areas of Urban Management, Higher Education management and Management of nonprofit organizations and Social enterprises. All the courses are designed by the faculty at IBA in consultation with FBR, which include Computer Skills, Communication and Presentation Skills, Management Skills, Leadership and Teambuilding Skills.

\section{MBA TAX MANAGEMENT PROGRAM FOR FBR}

This exclusive MBA program is only open to FBR executives. It was initiated in January 2005 at the Institute of Business Administration. The program which has produced a large number of MBA executives is instrumental in upgrading the quality of Human resource at FBR. The special curriculum encompasses the deeply enriched realms of accounting, finance, management, statistics and the local legal and business practices.

\section{CENTER FOR ENTREPRENEURIAL DEVELOPMENT}

United States of America has chosen the IBA for establishing a Center for Entrepreneurial Development in Pakistan under its broader Middle East and North African initiative. There will be a distinguished advisory panel titled as 'Blue Ribbon Panel', consisting of the Directors of Entrepreneurship Institutes at MIT, Babson, Harvard and Stanford. This panel will not only advise but also assist and support the new Pakistani Center. Dr. Peter Bearse, who is an international consulting economist and an expert in developing entrepreneurial center, is supervising the project. This Centre is important for boosting economic activity, employment and trade within the country and across the international markets. It will conduct research to identify training needs, document how entrepreneurship is developed and run in the country, the opportunities it offers and the obstacles it encounters. It will study and investigate rules and regulations for business conducting and give proposal for policy and procedural improvements. 


\section{CAREER DEVELOPMENT CENTER}

The goal of the Career Development Center is to help the students find the right job in the right field with the right employer. The center achieves this through developing strong and tangible linkages between employers and IBA graduates, aligning the needs of employers with the competencies of our graduates, organizing professional lectures, seminars, panel discussions and workshops on career development and related skills, organizing and facilitating job fairs, coordinating internships, and job placements in an efficient and smooth manner. The CDC also sponsors visits of talent hunting teams to facilitate on campus recruitment activities.

\section{RESEARCH CENTER}

Research is one of the top priorities at IBA. Our Centre for Business and Economic Research (CBER) aims to play a pro-active role in:

- Inviting proposals for award of research grants

- Organizing research seminars workshops/conferences

- Training in research proposal writing and research methodology

- Soliciting research ideas and funding from the industry and corporate sectors for core and contract research

- $\quad$ Establishing collaborative research projects with international and national institutions of repute

- $\quad$ Screening and prioritizing research studies to match the availability of researchers with the diverse demand originating from outside

- $\quad$ Publishing the working papers on the findings of research outputs and inviting comments for their conversion into papers for submission to journals

- Publishing and updating the Business Review at regular intervals

- Disseminating the research outputs and publications

The Center is a repository of the core research done by the IBA faculty, scholars and students. The research papers written are documented, archived and made available to other researchers and industry. The IBA faculty and students can access these research papers via the IBA internet.

\section{HIGH PROFILE FACULTY}

The IBA faculty comprises of $22 \mathrm{PhDs}$ and teachers with high academic achievements as well as successful, practical business management experience. Most have advanced degrees in their field of specialization from foreign institutes of repute. The faculty members are well regarded for their insight and command over current issues facing business and industry. The faculty ensures that the system of education at the IBA is a unique blend of the best in classroom instruction, case studies, role- 
playing, business games, research and practical training in business organizations.

\section{HIGH ACHIEVING STUDENTS}

Our students win distinctions and praises from foreign and local dignitaries for their confident, reasoned discourse, organized team work and knowledge. The IBA student groups arrange dozens of seminars and conferences every year. As individual contestants our students have been successful in national and international competitions. IBA students excel in many national and international level competitions including three awards in the National Model United Nations Conference in New York in April 2009, Second position in the Battle of Mind 2009 Competition. The IBA team has also won the 2009 CFA Investment Research Challenge and has been selected to represent Pakistan at the Asian Regional Challenge at Singapore. Only 78 schools from all over the world are partners of CFA Institute. Two IBA students were selected to attend the European Finance Seminar at Geneva. They were among a group of only 32 students selected from all over the world for this prestigious event.

\section{NATIONAL TALENT HUNT PROGRAM (NTHP)}

The growing income and regional inequalities in Pakistan necessitate that educational opportunities at institutions of excellence, such as IBA, are made available to talented and meritorious students from poor families and backward districts. To meet this objective, the IBA launched the National Talent Hunt Program (NTHP) in 2004. As of 2009, the program has been revamped with modern pedagogical tools and the intake standards have been revised to include only top 20 students of each board. The program primarily targets students from backward areas of Balochistan, Punjab, Sindh, FATA and Nothern areas who are unable to apply for admission in IBA due to financial constraints. Special coaching is given to the students to prepare them for IBA entry tests and provide full financial support to those who are selected for admission.

\section{Big Ideas}

...And then there is the upsurge in interest in Joseph Schumpeter's postulates of "dynamic disequilibrium" as the economy's only stable state; of the innovator's "creative destruction" as the economy's driving force; and of new technology as the main, if not the only, economic change agent - the very antitheses of all prevailing economic theories based on the idea of equilibrium as a healthy economy's norm, monetary and fiscal policies as the drivers of a modern economy, and technology as an "externality."

P.F. Drucker: Managing in the Next Society, PP. 2699 


\title{
IBA

\begin{abstract}
A Note for Contributors
This Journal is a peer reviewed biannual publication of the Institute of Business Administration, Karachi, Pakistan. It is a multidisciplinary Journal covering wide range of issues in the area of business, social and management sciences, administration and governance, mathematics and computer studies, finance, economics, psychology, business ethics, logic, history of ideas, and philosophy of comparative religion.
\end{abstract}

\section{GUIDELINES FOR AUTHORS}

1. Manuscript should be submitted to the Editor, Business Review, Institute of Business Administration, University Road, Karachi, Pakistan.

2. Three copies of the manuscript should be submitted.

3. The text should be double spaced, on one side of the quarto paper allowing wide margins for referee's comments.

4. All illustrations, tables, etc., should be placed on separate sheets, included with each copy. Their placement should be indicated in the text.

5. Footnotes should be numbered consecutively throughout the text.

6. The first page of the manuscript should contain the following information: (i) title of the paper; (ii) the name(s) and institutional affiliation(s) of the authors(s); (iii) a footnote should give the name, postal address, telephone and fax number, and an email address of the authors.

7. The second page must contain the title, an abstract not exceeding 300 words, 
a maximum of 5 key words or phrases and the appropriate JEL codes to be used for indexing purposes. The text will start on page number 3 .

8. Acknowledgements of all sorts should be included on the first page.

9. All mathematical derivations should be presented on a separate sheet (note to be published) to help the referees.

10. Manuscript should include only those references that are cited in the text. Authors are advised to follow American Psychological Association (APA) style of referencing.

11. All literary material, including books, journals and manuscript for review should be submitted in triplicate to the Editor, Business Review, Institute of Business Administration, University Road, Karachi, Pakistan.

12. It is assumed that the paper submitted is an original unpublished work and it has not already been published or submitted for publication elsewhere.

13. The opinion, ideas and evaluations expressed in the articles printed in the Business Review do not necessarily represent the views or polices of The Institute of Business Administration or the Editorial Board. They should be considered as representative examples of opinions and analysis now current in the academic field on various subjects of intellectual, educational and cultural interest.

14. After internal evaluation, the Editor will send the selected articles to the external referees or the consulting foreign editors for their evaluation. Selection of the referees will be the discretion of the Editor.

For advance electronic submission of the material:

businessreview@iba.edu.pk

tufail.qureshi@gmail.com

All enquiries should be addressed to the Editor, Business Review, Research Journal of The Institute of Business Administration, Karachi, Pakistan. 